\title{
Changes in total anthocyanin content and antioxidant activity in sweet cherries during frozen storage, and air-oven and infrared drying
}

\author{
Simona Oancea ${ }^{\star}$, Olga Draghici and Otto Ketney
}

Department of Agricultural Sciences and Food Engineering, Faculty of Agricultural Sciences, Food Industry and Environmental Protection, "Lucian Blaga" University of Sibiu, 7-9 Ion Ratiu Street, 550012 Sibiu, Romania

Received 10 March 2015 - Accepted 8 November 2015

\begin{abstract}
Introduction. Sweet cherries are important dietary components, based mainly on their content of antioxidant compounds related to health benefits. Different preservation procedures cause changes in the content of these compounds. Our work aimed at evaluation of changes in the total anthocyanin contents and antioxidant activities in fresh, frozen and dried sweet cherry fruits. Materials and methods. The total anthocyanin content of edible parts of sweet cherries was studied under different postharvest conditions. The total antioxidant activities were studied using total phenolic content and ferric reducing antioxidant power assays. Results and discussion. We report higher amounts of phenolics and anthocyanins in wild crops compared with orchard-grown and 'Black Gold' cultivars. Phenolics and anthocyanins of wild and cultivated samples degraded differently during frozen storage at $-18{ }^{\circ} \mathrm{C}$ for six months, with a more pronounced effect on anthocyanins than on phenolics, which retained approximately half of their amounts. Black Gold sweet cherries showed much less degradation than wild crops. We found good retention of anthocyanins in air-oven-dried sweet cherries for up to $8 \mathrm{~h}$ at $60{ }^{\circ} \mathrm{C}$ compared with infrared-dried cherries, which showed $48 \%$ anthocyanin degradation at $60{ }^{\circ} \mathrm{C}$. While anthocyanins drastically degraded at higher temperatures $\left(70-80{ }^{\circ} \mathrm{C}\right)$, the antioxidant activity increased. Conclusion. Fresh and processed sweet cherries may find potential applications as natural colorants, antioxidants and nutraceuticals, related to their content of phenolics/anthocyanins, antioxidant properties and intended use.
\end{abstract}

Keywords: Romania / sweet cherry / Prunus avium / anthocyanins / antioxidant / phenolics / food processing / postharvest management

Résumé - Modifications de la teneur en anthocyanes et de l'activité anti-oxydante des cerises douces au cours de
la congélation et du séchage au four ventilé ou par infrarouge. Introduction. Les cerises douces sont des aliments
dont l'intérêt nutritionnel est principalement basé sur leur teneur en composés anti-oxydants aux effets potentiels sur
la santé. Des changements de teneur en ces composés peuvent provenir des procédés de conservation utilisés. Notre
travail a visé à évaluer les changements de teneur en anthocyanes totales et des activités anti-oxydantes des fruits frais,
congelés et séchés. Matériel et méthodes. La teneur totale en anthocyanes des parties comestibles des cerises douces
a été étudiée sous différentes conditions post-récolte. L'activité anti-oxydante totale a été étudiée en utilisant le contenu
phénolique total et le test du pouvoir anti-oxydant par réduction du fer (FRAP). Résultats et discussion. Des quantités
plus élevées de composés phénoliques et d'anthocyanines ont été mesurées dans les cerises sauvages par rapport à
celles de vergers cultivés et aux cerises cv. Black Gold. Les composés phénoliques et les anthocyanes d'échantillons
de cerises sauvages et cultivées se sont dégradés différemment au cours des 6 mois de congélation à $-18{ }^{\circ} \mathrm{C}$, avec un
effet plus prononcé sur les anthocyanines que sur les composés phénoliques qui ont conservé environ la moitié de leur
teneur. Les cerises douces 'Black Gold' ont montré une dégradation beaucoup plus faible que les fruits sauvages. Une
bonne rétention des anthocyanes a été trouvée dans les cerises douces séchées au four ventilé jusqu'à $8 \mathrm{~h}$ à $60{ }^{\circ} \mathrm{C}$ par
rapport aux fruits séchés à l'infrarouge, qui ont montré $48 \%$ de dégradation des anthocyanes à $60{ }^{\circ} \mathrm{C}$. Alors que les
anthocyanes se sont considérablement dégradées aux températures élevées ( $70-80{ }^{\circ} \mathrm{C}$ ), l'activité anti-oxydante, elle,
s'est accrue. Conclusion. Les cerises douces fraîches et transformées peuvent trouver des applications comme colorants
naturels, comme anti-oxydants ou alicaments, grâce à leurs teneurs en composés phénoliques et anthocyanes, qui leur
confèrent des propriétés anti-oxydantes à valoriser.

Mots clés : Roumanie / cerise douce / Prunus avium / anthocyanes / activité anti-oxydante / composés phénoliques / agro-alimentaire / gestion post-récolte

\footnotetext{
^ Corresponding author: simona. oancea@ulbsibiu.ro
} 


\section{Introduction}

Most nutrition scientists generally accept that the diet greatly influences human health and biological evolution. Animal and epidemiological studies have shown increased longevity and decreased risk of chronic diseases associated with a significant increase in dietary antioxidants [1]. Fresh fruits and vegetables are good sources not only of essential nutrients, but also of phytochemicals such as phenolic compounds, which exert a protective role against oxidative damage [2]. Among phytochemicals, anthocyanins are considered essential bioactives based on their strong free radicalquenching abilities, providing a wide range of health benefits. Dietary sources of anthocyanins from edible plants belong in particular to the families Vitaceae, Rosaceae, Saxifragaceae, Ericaceae, Solanaceae and Cruciferae. From the Rosaceae family, sweet cherries Prunus avium L., wild and cultivated, are very popular fruits widely consumed worldwide, in particular in fresh form. Romania is an important sweet cherry producer with a production of $81,842 \mathrm{t}$ in 2011 , according to FAOSTAT official data, ranking in $7^{\text {th }}$ position after Turkey, the USA, Iran, Italy, Spain and the Russian Federation. Due to many hilly regions, favorable conditions are met for sweet cherry crop establishment in Romania. In our country, both indigenous varieties of sweet cherry and foreign ones adapted to specific local climate and soil conditions are cultivated. Sweet cherries are abundant in minerals, vitamins, phenolics and anthocyanins. It has been shown that sweet cherries exert various biological functions, such as antioxidant, anticancer and antiinflammatory [3-5]. Previous studies reported the total and individual contents of such bioactives in various sweet cherry cultivars from different geographic regions [6-8].

As sweet cherries are seasonal fruit, proper preservation technologies are required to obtain maximum health benefits through high retention of phenolics and anthocyanins, which are the main antioxidant compounds. Both thermal processing and freezing are traditional methods applied to reduce biochemical, chemical and microbiological deterioration. Frozen fruits are available throughout the year, but have limited applications, while dried fruits may find more applications through their incorporation into a wide range of food products. Regarding advanced preservation methods, results have shown the efficiency of sublimation and microwave-vacuum drying on preserving valuable food compounds $[9,10]$, but these are usually expensive.

Generally, it was shown that post-harvest storage at low temperatures of some cultivars of sweet cherry fruit lead to a decreased anthocyanin content [11], but other studies reported an increase during cold storage at $1-2{ }^{\circ} \mathrm{C}$ [6]. Preservation of the fruits through drying may be performed by several methods, with or without pre-treatments, in order to remove moisture from these products and preserve them for long periods of time. Traditionally, dried cherries are obtained through openair drying (sun, solar methods) with chemical pre-treatments. A great number of studies focused mainly on the characteristics of drying of sweet cherries [12], but less studies showed the impact on the phytochemical content [13].

The objectives of this study were: (i) to investigate the content of total anthocyanins (TA) and antioxidant activity by total phenolic (TP) assay in various genotypes/cultivars of sweet cherries grown in Romania, and (ii) to study the influence of fruit storage at $-18{ }^{\circ} \mathrm{C}$, and of drying (hot air and infrared techniques) on the bioactive content and on the total antioxidant activity as measured by ferric reducing antioxidant power (FRAP).

\section{Materials and methods}

\subsection{Plant material and reagents}

The fruits of sweet cherry (Prunus avium L.) used in the present investigation were randomly harvested in midJune 2013, as follows:

(1) wild-grown samples from Rasinari/Sibiu situated at an altitude of $573 \mathrm{~m}\left(45^{\circ} 40^{\prime} 12^{\prime \prime} \mathrm{N}, 24^{\circ} 01^{\prime} 35^{\prime \prime} \mathrm{E}\right)$,

(2) orchard-grown samples from Sibiu situated at an altitude of $415 \mathrm{~m}\left(45^{\circ} 47^{\prime} 45^{\prime \prime} \mathrm{N}, 24^{\circ} 09^{\prime} 08^{\prime \prime} \mathrm{E}\right)$, and

(3) cultivated dark red sweet cherries of the cv. Black Gold from Ciresoaia/Bistrita situated at an altitude of $414 \mathrm{~m}$ $\left(47^{\circ} 08^{\prime} 33^{\prime \prime} \mathrm{N}, 24^{\circ} 03^{\prime} 35^{\prime \prime} \mathrm{E}\right)$.

These regions are situated in central Romania and characterized by a temperate continental climate. The reported 2013 average annual temperatures were $10.2{ }^{\circ} \mathrm{C}$ in Sibiu and $9.9^{\circ} \mathrm{C}$ in Bistrita. Fruits were collected at commercial maturity as determined by the total soluble solids content. Fruits were sorted to eliminate damaged ones, and selected for uniform size of the cultivar (approximately 40 samples). Samples were immediately stored in a freezer at $-18{ }^{\circ} \mathrm{C}$ for 6 months.

Chemical reagents of analytical grade without further purification were used.

\subsection{Physico-chemical characterization of fruit}

The moisture content of the investigated samples was determined at $105^{\circ} \mathrm{C}$ using a moisture analyzer (MAC 210/NP, Radwag, Poland). The refractive index (n) and total soluble solids (TSS) of the sweet cherry juice obtained by manually pressing were measured by the refractometric method using an Abbe refractometer (Abbe AR2008, Krüss) at a standardized temperature $\left(21^{\circ} \mathrm{C}\right)$. Values are expressed as refractometric total soluble substances, ${ }^{\circ}$ Brix. Measurements were made in duplicate.

After physico-chemical characterization, samples were stored in a freezer at $-18{ }^{\circ} \mathrm{C}$ for 6 months in order to evaluate the influence of frozen storage on total anthocyanins and total phenolics. All samples were run in duplicate during analysis.

\subsection{Extraction and assay of total anthocyanins (TA)}

Fresh, frozen and dried fruits were homogenized and anthocyanins were extracted in acidified ethanolic solution at $4{ }^{\circ} \mathrm{C}$, for $24 \mathrm{~h}$. Optimized conditions for higher yields of anthocyanin extraction were initially determined, so that $0.1 \%$ $\mathrm{HCl}$ in $80 \% \mathrm{EtOH}(\mathrm{v} / \mathrm{v})$ was used for wild crops and $0.1 \%$ 
$\mathrm{HCl}$ in $60 \% \mathrm{EtOH}(\mathrm{v} / \mathrm{v})$ for cultivated crops. The extract was centrifuged at $8,000 \mathrm{rpm}$ for $10 \mathrm{~min}$ at $4{ }^{\circ} \mathrm{C}$. A refrigerated centrifuge (Hettich Universal 320R, Germany) was used. The content of total anthocyanins in the crude extracts obtained was determined spectrophotometrically by the $\mathrm{pH}$ differential method [14]. The content of total anthocyanins was expressed as milligram cyanidin-3-O-glucoside equivalent $100 \mathrm{~g}^{-1}$ fresh mass or dry mass (mg $100 \mathrm{~g}^{-1} \mathrm{FM} ; \mathrm{mg} 100 \mathrm{~g}^{-1} \mathrm{DM}$ ).

\subsection{Total antioxidant activity assays}

\subsubsection{Extraction and assay of total phenolics (TP)}

The total phenolic content was determined according to the Folin-Ciocalteu spectrophotometric method [15]. Briefly, the sweet cherry extract in $90 \%(\mathrm{v} / \mathrm{v})$ methanol $(1 \mathrm{~mL})$ was mixed with distilled deionized water and Folin-Ciocalteu reagent $(1 \mathrm{~mL})$ and incubated for $5 \mathrm{~min}$ at room temperature. Then, $7 \%(\mathrm{~m} / \mathrm{V}) \mathrm{Na}_{2} \mathrm{CO}_{3}$ solution was added. After incubation at room temperature for $90 \mathrm{~min}$, the absorbance at $745 \mathrm{~nm}$ was measured. The Specord 200Plus UV-Vis spectrophotometer (Analytik Jena, Germany) was used. Gallic acid was used as a standard for the calibration curve. The total phenolic content was expressed as milligram of gallic acid equivalents $100 \mathrm{~g}^{-1}$ fresh mass (mg GAE $100 \mathrm{~g}^{-1} \mathrm{FM}$ ).

\subsubsection{Ferric reducing antioxidant power (FRAP assay)}

The total antioxidant activity of sweet cherry anthocyanin crude extracts was determined by the ferric reducing ability assay described by Benzie and Strain [16]. The absorbance of the mixture of anthocyanin extracts and FRAP reagent was measured at $593 \mathrm{~nm}$ after $5 \mathrm{~min}$. The results were expressed as $\mathrm{mg}$ ascorbic acid $100 \mathrm{~g}^{-1}$ dry mass (DM)

\subsection{Drying methods}

Drying was carried out on samples stored in a freezer at $-18{ }^{\circ} \mathrm{C}$ for 6 months. For this investigation, samples were taken out of the freezer and thawed at room temperature before drying.

Air-oven drying: sweet cherry samples (orchard-grown, Sibiu, Romania) were cut into four pieces and placed in sieves in a single layer in a convection oven (UFE 400 with forced air circulation, Memmert) for up to $8 \mathrm{~h}$ at a maximum fan speed $(100 \%)$. Three sets of experiments were done at 60 , 70 and $80^{\circ} \mathrm{C}$, respectively.

Infrared drying: sweet cherry samples from the Sibiu orchard were cut into four pieces and placed in a moisture analyzer infrared heater (MAC 210/NP, Radwag, Poland) for up to $8 \mathrm{~h}$. Three sets of experiments were done at 60 , 70 and $80{ }^{\circ} \mathrm{C}$, respectively.

The equations that describe the regression exponential curves for the experimental data of drying obtained were calculated using Microsoft Office Excel 2007 for Windows.

\subsection{Statistical data analysis}

Results are presented as means \pm standard deviation (SD) of duplicate measurements. In order to summarize data regarding total anthocyanins and total antioxidant activity in dried sweet cherry samples, descriptive statistics were used to calculate the means of continuous variables, and to show the dispersion of these data. Levene's test for equality of variance and the ANOVA test were performed using statistical software (IBM SPSS.20). Differences were considered significant at $P<0.05$.

\section{Results and discussion}

\subsection{Physico-chemical characterization of various sweet cherry samples}

The total anthocyanin (TA) and total phenolic (TP) contents were investigated in three cultivars of sweet cherry fruits, wild-grown and cultivated in Romanian regions. The total phenolic content is frequently used to evaluate the antioxidant activity in herbal alcoholic extracts indirectly.

The wild cherry grown in Romania, also referred to as mountain cherry, had smaller fruits with black pigmentation in the skins and flesh. The sample collected from the orchard presented light red anthocyanin pigmentation in the edible parts, while the early-season cv. Black Gold had dark red skin and fruit flesh.

The main physico-chemical characteristics of the extracts and/or juices obtained are presented in table I. The total soluble solids (TSS) value expressed in ${ }^{\circ}$ Brix is often used as a quality control index in fruit processing, which indicates the fruit maturity and ripeness. A TSS range of 13.5-24.5 or $14.43-18.38^{\circ}$ Brix has already been reported $[11,15,17]$. The highest content of TP (275.94 mg GAE $\left.100 \mathrm{~g}^{-1} \mathrm{FM}\right)$ and TA (95.93 mg $\left.100 \mathrm{~g}^{-1} \mathrm{FM}\right)$ was found in the wild sweet cherries.

Karlidag et al. [18] reported TP values ranging from 148 to $321 \mathrm{mg}$ GAE $100 \mathrm{~g}^{-1}$ FM in six wild-grown sweet cherry genotypes. Kim et al. [7] reported lower amounts of TP (92 mg GAE $\left.100 \mathrm{~g}^{-1} \mathrm{FM}\right)$ and TA (30 mg $\left.100 \mathrm{~g}^{-1} \mathrm{FM}\right)$ in 'Black Gold' cherries than the values found by us (184.85 GAE $100 \mathrm{~g}^{-1} \mathrm{FM}$ and $44.19 \mathrm{mg} 100 \mathrm{~g}^{-1} \mathrm{FM}$, respectively). In a previous study, we reported that the content of TA in 'Black Gold' cherries is related to their extraction, as determined by conventional and ultrasound-assisted techniques [19]. Reported values of TA in edible parts of other sweet cherry cultivars related to the analytical method were as follows: (i) $0.5-29.0 \mathrm{mg} 100 \mathrm{~g}^{-1} \mathrm{FM}$ (quantification by the $\mathrm{pH}$ differential spectrophotometric method); (ii) $122.00-142.64 \mathrm{mg}$ $100 \mathrm{~g}^{-1} \mathrm{FM}$ (quantification by HPLC) [20,21].

Variable amounts of phenolics and anthocyanins in sweet cherries might be related to several factors, such as genetic, environmental, geographic location and maturity stage.

\subsection{Effects of freezing of sweet cherries on TA and TP content}

As sweet cherries are seasonal fruits, proper preservation technology may be required to have them available throughout the year. Selected samples of Romanian sweet cherries 
Table I. Physico-chemical attributes of the sweet cherry samples investigated. Data values are means \pm standard deviations of 2 analytical duplicates (FM: fresh mass; GAE: gallic acid equivalent; TA: total anthocyanins; TP: total phenolics; TSS: total soluble solids).

\begin{tabular}{|c|c|c|c|c|c|}
\hline $\begin{array}{l}\text { Sweet cherry fruits } \\
\text { (Romanian regions) }\end{array}$ & $\begin{array}{c}\text { Moisture } \\
(\%)\end{array}$ & $\begin{array}{c}\text { TSS } \\
\left({ }^{\circ} \text { Brix }\right)\end{array}$ & $\begin{array}{l}\text { Refractive index } \\
\text { (n) }\end{array}$ & $\begin{array}{c}\text { TP } \\
\left(\mathrm{mg} \mathrm{GAE} 100 \mathrm{~g}^{-1} \mathrm{FM}\right)\end{array}$ & $\begin{array}{c}\text { TA } \\
\left(\mathrm{mg} 100 \mathrm{~g}^{-1} \mathrm{FM}\right)\end{array}$ \\
\hline $\begin{array}{l}\text { Wild } \\
\text { (Sibiu) }\end{array}$ & $70.93 \pm 0.96$ & $21.71 \pm 0.34$ & $1.3656 \pm 0.0241$ & $275.94 \pm 5.40$ & $95.93 \pm 2.06$ \\
\hline $\begin{array}{l}\text { Orchard-grown } \\
\text { (Sibiu) }\end{array}$ & $82.42 \pm 0.50$ & $16.10 \pm 0.29$ & $1.3576 \pm 0.0222$ & $113.58 \pm 3.67$ & $21.33 \pm 1.73$ \\
\hline $\begin{array}{l}\text { cv. Black Gold } \\
\text { (Bistrita) }\end{array}$ & $78.90 \pm 0.61$ & $19.44 \pm 0.35$ & $1.3621 \pm 0.0261$ & $184.85 \pm 4.87$ & $44.19 \pm 1.38$ \\
\hline
\end{tabular}

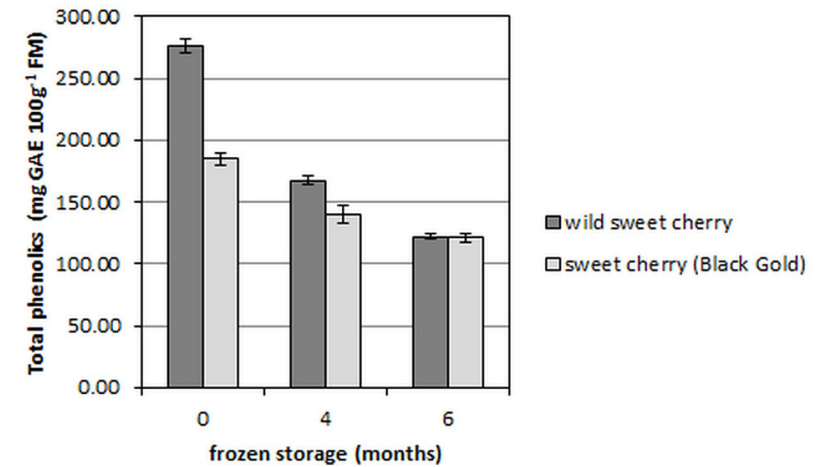

Figure 1. Total phenolic content (TP) in sweet cherry samples during storage at $-18{ }^{\circ} \mathrm{C}$ for 6 months. The bar graph illustrates the mean of TP values with error bars representing the standard deviation.

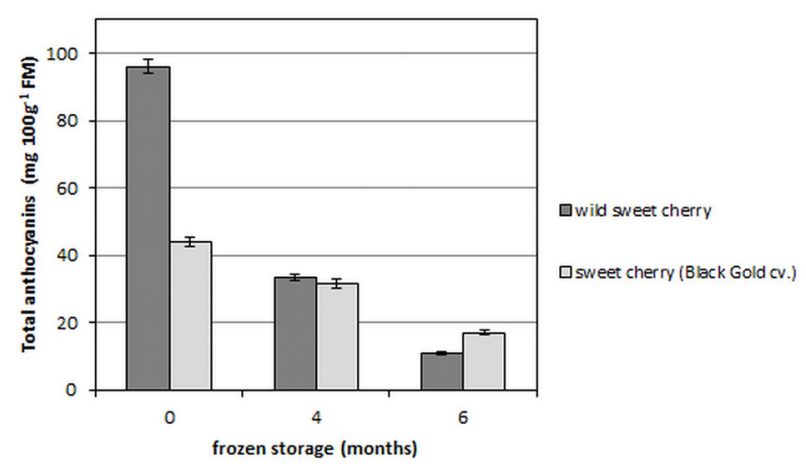

Figure 2. Total anthocyanin content (TA) in sweet cherry samples during storage at $-18{ }^{\circ} \mathrm{C}$ for 6 months. The bar graph illustrates the mean of TA values with vertical bars corresponding to standard deviation.

(wild and 'Black Gold' cultivars) were frozen without any pre-treatment for a limited period of time (up to 6 months) at $-18{ }^{\circ} \mathrm{C}$. The TP and TA were evaluated during the freezing period. The results, presented in figures 1, 2 indicate $55.67 \%$ loss of phenolics in wild cherries after 6 months of storage at $-18{ }^{\circ} \mathrm{C}$, and $88.54 \%$ loss of anthocyanins. In the case of the cv. Black Gold, much less degradation was found, as follows: $34.46 \%$ decrease in the phenolic content and $51.57 \%$ decrease in the anthocyanin level after the same storage period.
Our results showed a drastic degradation in anthocyanin pigments of the selected sweet cherry samples during frozen storage compared with phenolics, which retained approximately half of their amounts, which may explain the good antioxidant activity of frozen fruits showed by other authors [11], who reported 50\% phenolic degradation and $87 \%$ anthocyanin degradation in another cultivar of sweet cherry (cv. Bing) after 6 months of storage at $-23{ }^{\circ} \mathrm{C}$. Anthocyanin degradation during frozen storage was considered to be related to enzymatic transformations, in particular due to the native polyphenoloxidase [22].

There are studies reported by Gonçalves et al. [6] which showed that the anthocyanin level increased in another cultivar of sweet cherries (Van cv.) during cold storage at $1-2{ }^{\circ} \mathrm{C}$. To our knowledge, no studies regarding phenolic and anthocyanin degradation of wildgrown and 'Black Gold' sweet cherries by frozen storage have been reported.

\subsection{Effects of air-oven and infrared drying on TA and total antioxidant activity in sweet cherries}

The drying process of sweet cherry samples was performed at three different temperatures $\left(60,70\right.$ and $\left.80{ }^{\circ} \mathrm{C}\right)$ as an alternative choice of fruit preservation which may lead to wider applications in food products. The selected methods of drying were air-oven and infrared (IR) drying. These methods are characterized by different modes of heat transfer, thermal convection and radiation, respectively.

As the sweet cherry cultivar ('Black Gold') proved to suffer less anthocyanin and phenolic loss during the previously described freezing, we selected cultivated fruit samples of sweet cherry for the investigation of the effect of drying on targeted molecule (TA) and total antioxidant activity (TAC). Fruits were cut into four pieces and placed on sieves in the hotair oven. Forced air convection was set at $100 \%$ speed during the air-oven drying process. No pre-treatments of sweet cherry samples were done, as some authors suggested there was no influence on the anthocyanin level in dried cherries [13].

The changes in the moisture content with time of drying (air-oven and IR) are presented in figures 3-4. The best-fit curved lines are given in order to show the tendency of continuous decrease in moisture related to different drying temperatures. The air-oven drying technique led to a more intense moisture removal from the sweet cherry samples as a result of an increased hot airflow compared with IR drying. 


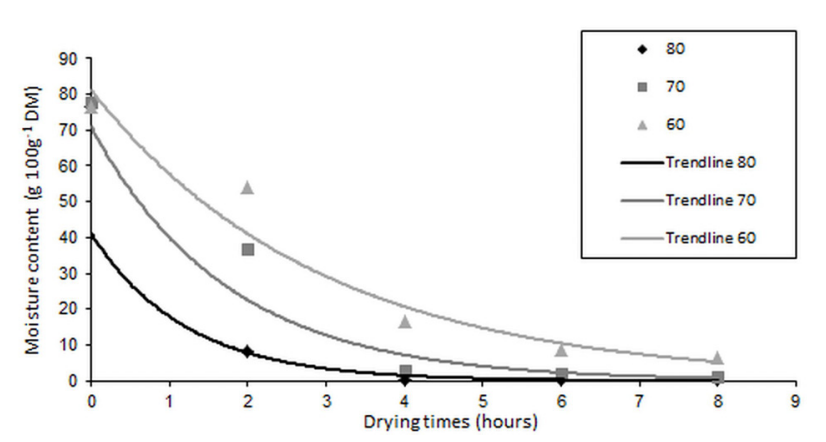

Figure 3. Drying curves of sweet cherry samples at 60,70 and $80{ }^{\circ} \mathrm{C}$ under air-oven drying.

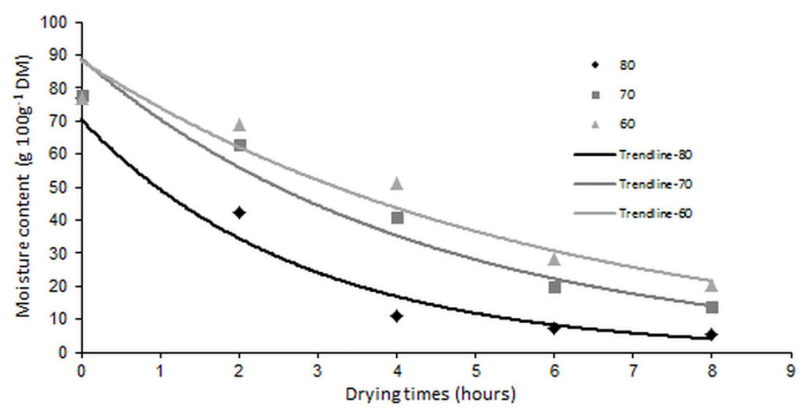

Figure 4. Drying curves of sweet cherry samples at 60,70 and $80{ }^{\circ} \mathrm{C}$ under infrared (IR) drying.

Table II. Model constants $a$ and $k$, and regression coefficients $\mathrm{R}^{2}$ for variation in moisture content with time.

\begin{tabular}{|c|c|c|c|c|c|c|}
\hline \multirow{2}{*}{$\begin{array}{l}\text { Drying } \\
\text { temperature } \\
\left({ }^{\circ} \mathrm{C}\right)\end{array}$} & \multicolumn{3}{|c|}{ Air-oven drying } & \multicolumn{3}{|c|}{ Infrared drying } \\
\hline & $a$ & $k$ & $\mathrm{R}^{2}$ & $a$ & $k$ & $\mathrm{R}^{2}$ \\
\hline 60 & 81.091 & 0.3412 & 0.9612 & 88.309 & 0.1763 & 0.9495 \\
\hline 70 & 70.777 & 0.5718 & 0.9164 & 88.869 & 0.2309 & 0.9698 \\
\hline 80 & 41.057 & 0.8314 & 0.9097 & 70.456 & 0.3575 & 0.9424 \\
\hline
\end{tabular}

Further, the Newton empirical drying model [23] was fitted to our experimental data. The model was slightly modified by describing the variation in the moisture content with time instead of the variation in the moisture ratio with time. The change in the moisture content with time was expressed by the following equation:

$$
M=a e^{-k t}
$$

where $M=$ moisture content $\left(\mathrm{g} 100 \mathrm{~g}^{-1} \mathrm{DM}\right) ; a, k=$ model coefficients; $t=$ time (h). The values obtained of $a$ and $k$, and the regression coefficients $\mathrm{R}^{2}$ are shown in table II.

According to the results presented in table II, the regression coefficients showed high values (0.9097-0.9698), which indicates good agreement between our experimental data and the chosen mathematical model of drying. Moreover, the $\mathrm{R}^{2}$ values are slightly higher for IR drying (average 0.9539) than for air-oven drying (average 0.9291).

The comparison of the two selected drying methods for the same drying temperature revealed a similarity regarding
Table III. Regression coefficients $\mathrm{R}^{2}$ of air-oven and infrared drying for different temperatures.

\begin{tabular}{lccc}
\hline Drying temperature $\left({ }^{\circ} \mathrm{C}\right)$ & 60 & 70 & 80 \\
\hline $\mathrm{R}^{2}$ & 0.928336 & 0.911288 & 0.919427 \\
\hline
\end{tabular}

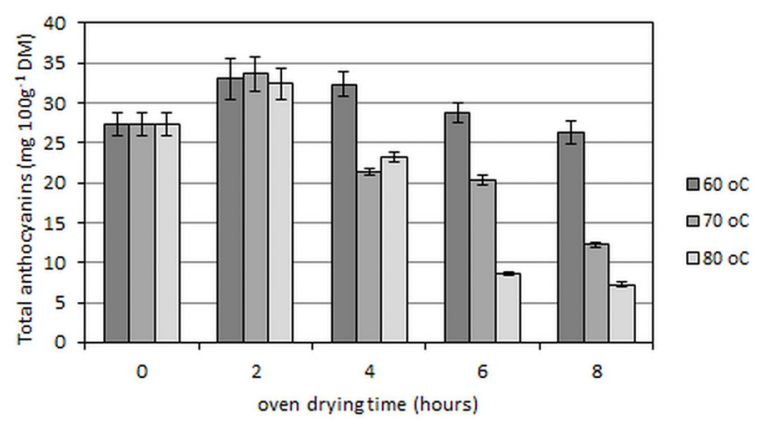

Figure 5. Total anthocyanin content in air-oven-dried sweet cherry samples at 60,70 and $80^{\circ} \mathrm{C}$. The bar graph illustrates the mean of TA values with vertical bars corresponding to standard deviation.

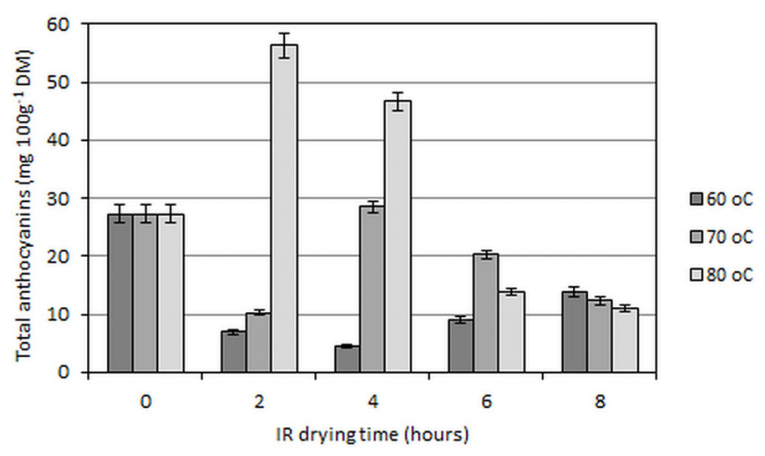

Figure 6. Total anthocyanin content (TA) in IR-dried sweet cherry samples at 60,70 and $80^{\circ} \mathrm{C}$. The bar graph illustrates the mean of TA values with vertical bars corresponding to standard deviations.

the change in the moisture content with time, as presented in table III. Experimental results regarding the TA content of airoven- and IR-dried cherry samples are shown in figures 5, 6. For homogeneous comparison reasons, the parameters studied were determined on a DM basis.

The descriptive statistical data regarding air-oven drying of sweet cherries showed decreasing mean values of TA content with an increase in drying temperatures: $29.50,22.95$ and $19.75 \mathrm{mg} 100 \mathrm{~g}^{-1} \mathrm{DM}$ at 60,70 and $80{ }^{\circ} \mathrm{C}$, respectively. There are no statistically significant differences among the oven drying temperatures $(P>0.05)$.

The results of the mean values of the TA content when considering the time of air-oven drying showed an initial slight increase during the first two hours and then a constant decrease during $8 \mathrm{~h}$ of drying. An increase of approximately $18.5 \%$ in the TA level was observed during the first couple of hours of air-oven drying of sweet cherries. At low air-oven drying temperatures $\left(60^{\circ} \mathrm{C}\right)$ the level increased constantly up to $8 \mathrm{~h}$, while at high temperature $\left(80^{\circ} \mathrm{C}\right) 74 \%$ of TA finally degraded. A different pattern was registered for IR drying of fruit up to $8 \mathrm{~h}$. 
Table IV. Variations in the total anthocyanin content (TA) in sweet cherries with drying temperature and time.

\begin{tabular}{|c|c|c|c|c|c|c|c|}
\hline \multicolumn{8}{|c|}{ Variation in TA content with drying temperature } \\
\hline \multirow{3}{*}{$\begin{array}{c}\text { Temperature } \\
\left({ }^{\circ} \mathrm{C}\right)\end{array}$} & \multirow[t]{3}{*}{ Mean } & \multicolumn{2}{|c|}{ ANOVA } & \multicolumn{4}{|c|}{ Correlations } \\
\hline & & \multirow{2}{*}{$F^{*}$} & \multirow{2}{*}{ Sig. ${ }^{* *}$} & Pearson $^{* * *}$ & Sig.** & Pearson $^{* * *}$ & Sig. ${ }^{* *}$ \\
\hline & & & & $\begin{array}{l}\text { Air-oven } \\
\text { drying }\end{array}$ & $\begin{array}{l}\text { Infrared } \\
\text { drying }\end{array}$ & $\begin{array}{l}\text { Air-oven } \\
\text { drying }\end{array}$ & $\begin{array}{c}\text { Infrared } \\
\text { drying }\end{array}$ \\
\hline 60 & 20.920 & \multirow[t]{3}{*}{0.400} & \multirow[t]{3}{*}{$P>0.05$} & \multirow[t]{3}{*}{-0.4763} & \multirow[t]{3}{*}{$P>0.05$} & \multirow[t]{3}{*}{0.5315} & \multirow[t]{3}{*}{$P<0.05$} \\
\hline 70 & 21.355 & & & & & & \\
\hline 80 & 25.381 & & & & & & \\
\hline \multicolumn{8}{|c|}{ Variation in TA content with drying time } \\
\hline \multirow{3}{*}{$\begin{array}{l}\text { Time } \\
\text { (h) }\end{array}$} & \multirow[t]{3}{*}{ Mean } & \multicolumn{2}{|c|}{ ANOVA } & \multicolumn{4}{|c|}{ Correlations } \\
\hline & & \multirow{2}{*}{$F^{*}$} & \multirow{2}{*}{ Sig. ${ }^{* *}$} & Pearson $^{* * *}$ & Sig. ${ }^{* *}$ & Pearson $^{* * *}$ & Sig. ${ }^{* *}$ \\
\hline & & & & \multicolumn{2}{|c|}{ Air-oven drying } & \multicolumn{2}{|c|}{ Infrared drying } \\
\hline 0 & 27.300 & 2.203 & $P>0.05$ & -0.6408 & $P<0.01$ & -0.3928 & $P>0.05$ \\
\hline 2 & 28.726 & & & & & & \\
\hline 4 & 26.116 & & & & & & \\
\hline 6 & 16.771 & & & & & & \\
\hline 8 & 13.845 & & & & & & \\
\hline
\end{tabular}

* Fisher significance factor; $* *$ significance level; *** Pearson correlation coefficient.

However, after $8 \mathrm{~h}$ of IR drying, $54.3 \%$ anthocyanin degradation occurred at all three temperatures.

Regarding the statistical correlations, as illustrated in table $I V$, a negative correlation of linear regression was found between the TA content and air-oven drying time $(-0.6408)$ or IR drying time $(-0.3928)$, while a positive correlation between the TA content and IR drying temperature was found (0.5315) compared with a negative correlation with the air-oven drying temperature $(-0.4763)$. No statistically significant differences $(P>0.05)$ were found between TA content and drying temperatures, but high variation was registered at $80{ }^{\circ} \mathrm{C}$ for both drying processes, which emphasizes the degradation of such products at high temperatures. No statistically significant differences $(P>0.05)$ were found between TA content and drying times by both drying processes.

Based on the results obtained, the optimal values of processing parameters in relation to TA content suggest up to $8 \mathrm{~h}$ for air-oven drying of sweet cherries at $60{ }^{\circ} \mathrm{C}$ in order to reach a moisture content of $6.26 \%$. Despite the fact that IR drying of sweet cherries followed a very different and heterogeneous pattern, it seems that drying at high temperature $\left(80^{\circ} \mathrm{C}\right)$ for a short time (up to $4 \mathrm{~h}$ ) may lead to a significant increase in the TA level in dried cherries with $11 \%$ final moisture content. This might be due to the transformation products (copigmentation) during IR drying, resulting in compounds which retained significant red color. After this period of IR drying, anthocyanin degradation occurred. There is a lack of publications regarding the influence of IR drying on sweet cherry anthocyanins, but Lai et al. [24] reported good retention of anthocyanins from grape pomace during catalytic infrared drying. This may suggest an effective method of sweet cherry preservation compared with conventional heat drying, which usually employs longer drying times.

Further, studies concerning the influence of drying conditions on the TAC were performed. As the TP content was previously chosen to indirectly determine the TAC as an electron-based assay, for the present study a similar ferric ion reducing antioxidant power (FRAP) assay was selected as a simple, rapid and inexpensive method for direct TAC estimation of dried fruits (table $V$ ).

The descriptive statistical data regarding the TAC showed an increase in mean values, with an increase in temperature from 60 to 70 and $80{ }^{\circ} \mathrm{C}$ of air-oven-dried sweet cherries, as follows: $317.942,332.055$ and $360.322 \mathrm{mg}$ ascorbic acid $100 \mathrm{~g}^{-1} \mathrm{DM}$, respectively. The differences among the oven drying temperatures are not statistically significant $(P>0.05)$. Regarding the IR drying, the pattern of mean values was quite different: 242.018, 367.782, and $307.094 \mathrm{mg}$ ascorbic acid $100 \mathrm{~g}^{-1} \mathrm{DM}$ at 60,70 and $80{ }^{\circ} \mathrm{C}$, respectively. The differences among the IR drying temperatures are not statistically significant $(P>0.05)$. However, the mean TAC values showed a decrease of $13.78 \%$ in TAC at $60^{\circ} \mathrm{C}$ compared with the control value (314.665 $\mathrm{mg}$ ascorbic acid $\left.100 \mathrm{~g}^{-1} \mathrm{DM}\right)$ and an increase of $18.13 \%$ at $80^{\circ} \mathrm{C}$ after $8 \mathrm{~h}$ of drying by both processes investigated. Our results are in accordance with previously reported results on air-dried plums [25], and on apricots dried in an air-flow cabinet [26].

The increase in the TAC and decrease in the TA level at high temperature is probably correlated with the higher antioxidant power of the oxidation intermediate states of antioxidant compounds (polyphenols), the higher content of reducing sugars and products of the Maillard reaction (there are approximately $12 \%$ reducing sugars and $1 \%$ proteins in sweet cherry) [27], as shown by other authors but in other processed foods $[28,29]$. The nutritional quality of dried sweet cherries and the economic aspect (in particular energy consumption) regarding different drying technologies are relevant issues to be considered before deciding the industrial application of various conventional or modern processing technologies. 
Table V. Total antioxidant activity as determined by FRAP assay of crude extracts of oven- and infrared-dried sweet cherry samples at 60 , 70 and $80^{\circ} \mathrm{C}$. Results are expressed as means \pm standard deviations of two analytical duplicates.

\begin{tabular}{lllllll}
\hline \multirow{2}{*}{$\begin{array}{l}\text { Drying } \\
\text { time }\end{array}$} & \multicolumn{5}{c}{ FRAP $\left(\mathrm{mg}\right.$ ascorbic acid $\left.100 \mathrm{~g}^{-1} \mathrm{DM}\right)$} \\
\cline { 2 - 7 }$(\mathrm{h})$ & \multicolumn{3}{c}{ Air-oven drying temperature $\left({ }^{\circ} \mathrm{C}\right)$} & \multicolumn{3}{c}{ Infrared drying temperature $\left({ }^{\circ} \mathrm{C}\right)$} \\
\hline 0 & $314.665 \pm 11.795$ & $314.665 \pm 11.795$ & $314.665 \pm 11.795$ & $314.665 \pm 11.795$ & $314.665 \pm 11.795$ & $314.665 \pm 11.795$ \\
2 & $353.584 \pm 13.434$ & $354.699 \pm 7.629$ & $335.868 \pm 5.658$ & $255.174 \pm 4.054$ & $331.250 \pm 4.180$ & $227.904 \pm 12.266$ \\
4 & $349.103 \pm 10.153$ & $334.146 \pm 3.076$ & $371.546 \pm 3.876$ & $196.234 \pm 5.316$ & $560.512 \pm 29.302$ & $308.954 \pm 10.614$ \\
6 & $331.568 \pm 3.118$ & $337.124 \pm 6.164$ & $388.212 \pm 7.482$ & $216.320 \pm 5.980$ & $347.387 \pm 10.664$ & $325.450 \pm 5.270$ \\
8 & $240.789 \pm 3.449$ & $319.642 \pm 1.752$ & $391.319 \pm 6.229$ & $227.696 \pm 3.356$ & $285.096 \pm 15.044$ & $358.496 \pm 16.736$ \\
\hline
\end{tabular}

\section{Conclusion}

The overall conclusion of our study is that sweet cherry fruits selected from different Romanian regions contain variable amounts of total phenolics and anthocyanins based on genetic and environmental conditions, with higher amounts for wild crops. Freezing of fruit $\left(-18^{\circ} \mathrm{C}\right)$ for six months had a more pronounced effect on anthocyanins than on phenolics, which retained about half of their amounts, while air-oven drying at lower temperatures $\left(60{ }^{\circ} \mathrm{C}\right)$ for a shorter period of time may not greatly influence the content of these phytochemicals and the total antioxidant activity. Anthocyanins were drastically degraded at higher temperatures $\left(70\right.$ or $\left.80{ }^{\circ} \mathrm{C}\right)$ by the airoven and IR drying processes. Both fresh and processed sweet cherries may find potential applications as natural colorants, antioxidants and nutraceuticals, in relation to their contents of phenolics and anthocyanins, and antioxidant properties.

Acknowledgements. This work was supported by a grant from the Romanian National Authority for Scientific Research, CNCS - UEFISCDI, project number PN-II-ID-PCE-2011-3-0474.

\section{References}

[1] Stanner S.A., Hughes J., Kelly C.N.M., Buttriss J., A review of the epidemiological evidence for the 'antioxidant hypothesis', Public Health Nutrition 7 (2004) 407-422.

[2] Prior R.L., Fruits and vegetables in the prevention of cellular oxidative damage, Am. J. Clin. Nutr. 78 (2003) 570-578.

[3] Heinonen M., Meyer, A.S., Frankel E.N., Antioxidant activity of berry phenolics on human low-density lipoprotein and liposome oxidation, J. Agr. Food Chem. 46 (1998) 4107-4111.

[4] Kang S.Y., Seeram N.P., Nair M.G., Bourquin L.D., Tart cherry anthocyanins inhibit tumor development in Apc(Min) mice and reduce proliferation of human colon cancer cells, Cancer Lett. 194 (2003) 13-19.

[5] Kelley D.S., Rasooly R., Jacob R.A., Kader A.A., Mackey B.E., Consumption of Bing sweet cherries lowers circulating concentrations of inflammation markers in healthy men and women, J. Nutr. 136 (2006) 981-986.

[6] Gonçalves B., Landbo A.-K., Knudsen D., Silva A.P., Moutinho-Pereira J., Rosa E., Meye, A.S., Effect of ripeness and postharvest storage on the phenolic profiles of cherries (Prunus avium L.), J. Agr. Food Chem. 52 (2004) 523-530.

[7] Kim D.O., Heo H.J., Kim Y.J., Yang H.S., Lee C.Y., Sweet and sour cherry phenolics and their protective effects on neuronal cells, J. Agr. Food Chem. 53 (2005) 9921-9927.
[8] Gonźalez-Gómez D., Lozano M., Fernández-León M.F., Bernalte M.J., Ayuso M.C., Rodriguez A.B., Sweet cherry phytochemicals: Identification and characterization by HPLCDAD/ESI-MS in six sweet-cherry cultivars grown in Valle del Jerte (Spain), J. Food Comp. Anal. 23 (2010) 533-539.

[9] Michalczyk M., Macura R., Matuszak I., The effect of airdrying, freeze-drying and storage on the quality and antioxidant activity of some selected berries, J. Food Process. Preserv. 33 (2009) 11-21.

[10] Clary C.D.,Wang S., Petrucci V.F., Fixed and incremental levels of microwave power application on drying grapes under vaccum, J. Food Sci. 70 (2005) 344-349.

[11] Chaovanalikit A., Wrolstad R.E., Anthocyanin and polyphenolic composition of fresh and processed cherries, J. Food Sci. 69 (2004) 73-83.

[12] Doymaz I., Ismail O., Drying characteristics of sweet cherry, Food Bioprod. Process. 89 (2011) 31-38.

[13] Elrashid A.A., Iqbal N., Dehydration characteristics of sweet cherries (Prunus avium L.), Pak. J. Biol. Sci. 3 (2000) 231-235.

[14] Wrolstad R.E., Schwartz S.J., Current Protocols in Food Analytical Chemistry, John Wiley \& Sons, Inc. New York, 2001.

[15] Singleton V.L., Rossi J.A. Jr., Colorymetry of total phenolics with phosphomolybdic-phosphotungstic acid reagents, Am. J. Enol. Vitic. 16 (1965) 144-158.

[16] Benzie F.F.I., Strain J.J., The ferric reducing ability of plasma (FRAP) as a measure of "antioxidant power": the FRAP assay, Anal. Biochem. 239 (1996) 70-76.

[17] Wang H., Nair M.G., Iezzoni A., Strasburg G.M., Booren A.M., Gray J.I., Quantification and characterization of anthocyanins in Balaton tart cherries, J. Agr. Food Chem. 45 (1997) 2556-2560.

[18] Karlidag H., Ercisli S., Sengul M., Tosun M., Physico-chemical diversity in fruits of wild-growing sweet cherries (Prunus avium Ehrh.), Biotechnol. Biotec. Eq. 23 (2009) 1325-1329.

[19] Oancea S., Grosu C., Ketney O., Stoia M., Conventional and ultrasound-assisted extraction of anthocyanins from blackberry and sweet cherry cultivars, Acta Chim. Sloven. 60 (2013) 383-389.

[20] Mozetic B., Trebse P., Identification of sweet cherry anthocyanins and hydroxycinnamic acids using HPLC coupled with DAD and MS detector, Acta Chim. Sloven. 51 (2004) 151-158.

[21] Kelebek H., Selli S., Evaluation of chemical constituents and antioxidant activity of sweet cherry (Prunus avium L.) cultivars, Int. J. Food Sci. Technol. 46 (2011) 2530-2537.

[22] Pifferi P.G., Cultrera R., Enzymatic degradation of anthocyanins: the role of sweet cherry polyphenoloxidase, J. Food Sci. 39 (1974) 786-791

[23] Adabi M.E., Nikbakht A.M., Motevali A., Mousavi Seyedi S.R., Investigation of black mulberry drying kinetics applying different pretreatments, J. Agric. Sci. Technol. 15 (2013) 23-34. 
[24] Lai K.P., Matella N.J., Dolan K.D., Effects of catalytic infrared and conventional drying on anthocyanin retention in dried grape pomace 33F-4, IFT Annual Meeting, July 12-16 2004- Las Vegas, NV.

[25] Piga A., Del Caro A., Corda G., From plums to prunes: influence of drying parameters on polyphenols and antioxidant activity, J. Agr. Food Chem. 51 (2003) 3675-3681.

[26] Madrau M.A., Piscopo A., Sanguinetti A.M., Del Caro A., Poiana M., Romeo F.V., Piga A., Effect of drying temperature on polyphenolic content and antioxidant activity of apricots, Eur. Food Res. Technol. 228 (2009) 441-448.
[27] USDA National Nutrient Database for Standard ReferenceRelease 26, Full Report 09070, Cherries, sweet, raw. 2014.

[28] Manzocco L., Calligaris S., Mastrocola D., Nicoli M.C., Lerici C.R., Review of non-enzymatic browning and antioxidant capacity in processed foods, Trends Food Sci. Tech. 11 (2001) 340-346.

[29] Morales F.J., Jimenez-Perez S., Free radical scavenging capacity of Maillard reaction products as related to colour and fluorescence, Food Chem. 72 (2001) 119-125.

Cite this article as: Simona Oancea, Olga Draghici and Otto Ketney. Changes in total anthocyanin content and antioxidant activity in sweet cherries during frozen storage, and air-oven and infrared drying. Fruits 71 (2016) 281-288. 